\title{
ANALYSIS OF ENTREPRENEURSHIP DEVELOPMENT MODEL ON MICRO, SMALL AND MEDIUM ENTERPRISES ENTITIES IN BADUNG MARKET AREA, DENPASAR CITY
}

\author{
Ni Wayan Oktiviantari ${ }^{1}$, IB. Teddy Prianthara ${ }^{2}$ \\ Undiknas Graduate School, Indonesia \\ Viantariokti88@gmail.com¹, ibtp4563@gmail.com²
}

\begin{abstract}
This research aims to observe the efforts done by the MSME (Micro, Small and Medium Enterprises) entities in developing the entrepreneurship and to observe the difficulties which were encountered by the MSME entities in the process of entrepreneurship development. This research was designed by using qualitative approach. The location of this research is in the area of Badung Market in Denpasar City. The primary data is obtained through the research informants. The informants in this research are the MSME entities in Badung Market area in Denpasar. The data validation testing was done using data triangulation. The data were analysed using the descriptive qualitative technique. The result shows that the entrepreneurship model which is done in Badung Market is based on the togetherness concept. This togetherness concept means the concept is of the people, by the people and for the people. The development process makes the MSME entities in Badung Market, Denpasar more creative and aware in seeing any opportunities to open a new business. This process is certainly influenced by many factors, both internal and external such as, education, sociology, organization, tradition and environment. Those factors formed locus of control, creativity, innovation, implementation, and growth which then will develop to become a great entrepreneur. The development process is divided into some development stages which are innovation process, support process, implementation process and growth process.
\end{abstract}

Keyword: entrepreneurship development model, micro, small and medium enterprises

\section{INTRODUCTION}

Hisrich et. al. in Selamet dkk. (2018:3) define entrepreneurship as a process of creating something new which has a value. It is done by sacrificing time and energy, taking financial, physic and social risk and also receiving monetary reward, personal satisfaction and freedom. Entrepreneurship is a process of creating something with a different value by using energy and time, carrying a financial, psychology and social risk and also in return, receiving monetary reward and selfsatisfaction. Whereas, according to Frank Knight (Naomy, 2013), entrepreneurship is an entrepreneur who tries to predict and respond the market change. The definition emphasizes the entrepreneur role in facing uncertainty of market 
dynamic. An entrepreneur is required to perform the basic managerial functions such as direction and control.

According to Hisrich in Alma (2017:23), entrepreneurship is a process of creating something different by dedicating all the time and energy and also bearing financial, psychological, social risks as well as receiving recompense in the form of money and personal satisfaction. Entrepreneurship is a dynamic, risk-taking, reactive and growth-oriented behaviour. It is a person who is willing to take action to pursue opportunity in a situation which is seen as a problem or threat for some people (Agustina, 2019: 3).

Entrepreneur is a person who sees an opportunity then creates an organization to utilize that opportunity. Whereas entrepreneurship process consists of all functional activities and actions in order to pursue and utilize the opportunity in creating an organization (Dharmawati, 2017:13). Prawirokusumo in Suryana (2013) argues that entrepreneur is someone who does creative and innovate efforts such as developing an idea and resource in order to find an opportunity and enhancement of life.

One of the regions in Bali that endeavour in developing entrepreneur through the Balinese local culture is Denpasar city. Denpasar is an open city and has an amazing attraction because of its uniqueness and tradition. As an open city, the presence of comers such as tourists, job seekers and young entrepreneurs leads to the faster development of IT (information technology) in there. The presence of complete and great education facility also attracts the young comers. This will surely make the competition get fiercer. Those who are not well prepared will be left behind (Lestari, 2015). Therefore, creative city development needs a great collaboration in strategic partnership relationship framework between the city leader and local universities in order to build small industry. The development of Denpasar creative city must be different than the other regions. This happened because of its tradition. The inventory of superior cultural elements that has been carried out by the Government of Denpasar City is aimed as a fundamental effort in building the foundation of Denpasar development as a creative city based on the leading culture. (Gerilya, 2010: 34).

The development of Denpasar City as a creative city is also supported by the Badung Market revitalization which was inaugurated recently by the President of Republic of Indonesia, Mr. Joko Widodo. If we talk about the revamping of Badung Market, many new things had appeared after it is happened. Moreover, Badung Market has facilities like a modern mall which did not exist in Badung Market before, even in other traditional markets.

Traditional retail is a form of retail which the trading activity is based on the conventional method (Suhartanto dkk.,2017:2). Retail has a basic difference with the traditional market. Traditional market is related with the traditional elements, which are community system and organization and also related with the livelihood system (Suartha, 2016:10).

What makes traditional market different than the modern market is, the seller and buyer can bargain directly in traditional market. The products are mainly daily needs. Meanwhile, the products in modern market are traded with fix price and it is self-service. Some types of modern market are mall, plaza and other modern places (Suartha, 2016:11). 
Badung Market is the biggest traditional market in Denpasar which becomes a place that is visited a lot by domestic tourist as well as foreigners. In this market, the varieties of needs are sold, such as basic needs, traditional foods with its uniqueness, Balinese art items, etc. The existence of Badung Market cannot be separated from the businesses inside it. One of them is the presence of MSME (Micro, Small and Medium Enterprises). The presence of MSME is very important. It gives a big contribution in economic development since it enlarges the employment opportunity and provides broad economic service to the community. It also plays a role in the process of economic equality, increasing of community's income, boosting the economic development as well as objectifying the stability of the State. The presence of many MSME entities in Denpasar City is a great asset which may strengthen the foundation of regional economic.

As time goes by, the global development has been growing rapidly. It makes Denpasar city anxious about their effort to maintain the existence of Balinese custom and culture against the modern era. This happened because the lack of human resource and the limited community experience which is not equal with the external challenge. Besides, the development of era and technology affects the shifting of livelihood and communication pattern of the community. In order to anticipate that problem and to avoid the bad external influence, a good quality of human resource is needed. With the good quality of human resource, it may create creative ideas in order to create Denpasar City as a creative city which would boost the economic development in Denpasar.

The result of the research by Darwanto (2012) states that entrepreneur has an important role in the productivity activity which boost the economic development of a country. A new business surely forms an employment opportunity, decreases the unemployment and increases the community's wealth. Meanwhile, the research conducted by Putri and Alit (2016) states that some factors which influence the intensity of entrepreneurship are family context, entrepreneurial skill and locus of control. In developing the intensity of entrepreneurship, these three factors are highly related to the continuity of business activity.

This research aims to observe the efforts done by the MSME (Micro, Small and Medium Enterprises) entities in developing the entrepreneurship and to observe the difficulties which were encountered by the MSME entities in the process of entrepreneurship development.

\section{METHODOLOGY}

This research was designed by using qualitative approach. The location of this research is in the area of Badung Market in Denpasar City. The data source in this research is a primary data which is obtained through the research informants. The informants in this research are the MSME entities in Badung Market area in Denpasar. The data validation testing was done using data triangulation. The data were analysed using the descriptive qualitative technique. 


\section{RESULT AND DISCUSSION \\ 1. The Entrepreneurship Development Model on MSME Entities in Badung Market Area, Denpasar City}

A model can be defined as a design which is simplified from an activity system but it can represent the real activity system. Gordon (2013) defines that model is a conceptualized information which is used as a reference to continue the empiric research in discussing a problem.

A development model refers to the portrait of learning in order to make the product as a blue print from the development itself. It also refers to the good quality of human resource which is in line with the aim of the development itself. Badung Market in Denpasar uses the development model on MSME entities with the way of increasing the human resource through the trainings. The trainings are done by PD Pasar Kota Denpasar (Localized Company's Market of Denpasar City).

Joyce, et.al. (2011) state that a development model is classified into four families, which are:

1. The information processing family

The information processing family is a model which defines how the individual gives respond which come from their environment. It includes data organization, problem formulation, concepts building, problem solve planning and the use of verbal and non-verbal symbols. This model focuses on developing creative ability and potential to learn about the individual from MSME entities in Badung Market, Denpasar City.

The information processing is done by PD Pasar Kota Denpasar (Localized Company's Market of Denpasar City) by collecting the MSME entities in Badung Market, Denpasar City with the aim to give information about the regulation of Badung Market on behalf of PD Pasar Kota Denpasar (Localized Company's Market of Denpasar City).

2. The personal family

The personal family is a development model which focuses on the development of seller's personality by paying attention to their emotion. The development process is directed hoping that the sellers can understand their selves, responsible for their aims in order to be independent, productive and to have a better life.

In this case, PD Pasar Kota Denpasar (Localized Company's Market of Denpasar City) has been working together with the educational institutions in order to create a good character of the sellers. Besides, the MSME entities in Badung Market, Denpasar City also have a cooperative to help their economic problem. With the presence of cooperative, therefore the sellers will feel emotionally secure in entrepreneurship. This makes the sellers of Badung Market more focus in running their business with the result that they can make innovation in developing their business. The entrepreneurs may still pay attention to the environment and feel responsible to the Badung Market area.

3. The social family

The social family is a model which values individual's ability to make a good relationship with people and focuses their attention to a process where reality is seen as a social negotiation. The social family is made by taking the advantage of the cooperation phenomenon. Therefore, the MSME entities as a group will be able to define problem, exploring it, collecting then testing the relevant data as well 
as developing hypothesis in order to developing the concept of human resource development.

In order to maintain a good relationship between each of the MSME entities in Badung Market, they created an organization such as cooperative. With the presence of cooperative, it may create a multiplier effect such as suppliers.

4. The behavioral system family

The behavioral system family is made based on the theoretical framework of behavior change. Therefore, the development is done systematically and focuses on some small behaviors which are not comprehensive. This development also focuses on the action and behavior of the seller. With the purpose to give more knowledge and skill for the seller, PD Pasar Kota Denpasar (Localized Company's Market of Denpasar City) has been working together with the educational institutions. This is as a form of commitment from Government of Denpasar City in developing a traditional market based on the tradition.

Communication and socio-cultural instruments are used in the effort to change the seller's mindset, such as the laws which prioritize the Balinese local tradition. These activities are summarized in Bali sublime philosophy which is recognized by UNESCO, namely the Tri Hita Karana (Narottama, et al: 2017). Then, the business which is done by using the concept of togetherness will give an impact to Tri Hita Karana. Thus, Tri Hita Karana will become the reference in doing the entrepreneurship development which had been started with the revitalization of Badung Market. Tri Hita Karana consists of Parhyangan (harmony between human and God), Pawongan(harmony between human), andPalemahan (harmony between human and earth).

\section{The Process of Entrepreneurship Development on MSME Entities in Badung Market Area, Denpasar City}

According to Sulastri (2017), the process of entrepreneurship development is started with the innovation. The innovation is influenced by many factors both internal and external, such as education, sociology, organization, tradition and environment. Those factors create locus of control, creativity, innovation, implementation and development to become a great entrepreneur. Innovation is influenced with the internal factors that come from the individual such as locus of control, tolerance, values, knowledge as well as experience. On the other hand, the external factors consist of role model, activity and opportunity. Therefore, innovation develops to an entrepreneurship through the process which is influenced by environment, organization and family (Suryana, 2013).

The process of entrepreneurship development consists of some stages (Sulastri, 2017):

1. Innovation Process

a. The desire to achieve

In this process, the MSME entities are triggered by the desire to achieve. The entrepreneurs in Badung Market always want to develop their own business. This makes them always want to upgrade the service quality, taste quality and price, in order to create a branding and specialty of their product for the buyer. Moreover, the entrepreneur applies innovation in developing their business in order to get an optimum profit. 
It can be seen from the variation of the product which has been increasing from years to years. Besides, the product also has a better quality. This happens, because there are many coaching and training by the competent intuitions to support the entrepreneur's skill in giving service to the buyers.

b. Opportunity

Badung Market has been growing rapidly. Therefore it is used by the sellers as an opportunity. The opportunity arises from the huge variety of community's needs. The presence of Badung Market establishes an economic chain in Denpasar City and also new entrepreneur such as the suppliers which came from Bali area and outside of Bali.

c. Creativity

Many existed opportunities make the sellers become more creative as an entrepreneur. It is needed in creating Badung Market as a traditional market with the modernization. Therefore, it will become a tourist destination. Moreover, the regulation program of traditional market and river revitalization seems to make Denpasar famous throughout the country. The regulation of traditional market and river is a development program from Government of Denpasar City to give comfort for buyers. This thing surely brings a positive effect to Denpasar city which makes the community more eager to preserve the Balinese tradition.

\section{Support Process}

a. The support process comes from the resources that can be utilized such as saving, fund, legacy, or owning building on strategic location

The strategic location of Badung Market supports the Denpasar community to do business. It is located on the center of the city and also near the tourist destinations such as Sanur. It is one of the reasons of the business establishment that owned by Denpasar community.

b. Joining trainings, coaching or trying to gain more knowledge and education

By joining business coaching or trainings and trying to gain more knowledge, it is hoped that entrepreneurs become more successful in their business. The trainings are prepared by a competent business coach. It is hoped that the sellers can discover their business potential which can be developed.

These trainings are usually done by PD Pasar Kota Denpasar (Localized Company's Market of Denpasar City). For example, customer service training or personality development which are needed to support their entrepreneurship in Badung Market. The training which is done by PD Pasar Kota Denpasar (Localized Company's Market of Denpasar City) for the MSME entities in Badung Market is sustainable which means not only happen once.

3. Implementation Process

In this process, the commitment and the existence of administrator of Badung Market are two of the factors of the establishment of entrepreneurship from the sellers. The commitment from Government of Denpasar City in creating and developing entrepreneurship based on togetherness concept (of the people, by the people and for the people) made Denpasar people always try to create new businesses. 
Besides, with the technology development like nowadays, the noncash payment is now applied in Badung Market. Not only to pay seller's contribution fee, but the consumers can also use electronic transaction during shopping. In order to support the market activity to be more modern, Government of Denpasar City has been working together with GO-JEK through GoPay application. GoPay or known before as Go Wallet is a virtual wallet which saves GO-JEK Credit. GO-JEK Credit is used to pay some transactions which are related to the services on GO-JEK application. There are some steps to use Go-Pay. First, open GO-JEK app, then click scan QR. After that, scan the QR Go-Pay code which is given by the seller or through the receipt. Then, input the nominal along with the Go-Pay PIN. Finally, the consumers have successfully paid with using electronic money automatically.

The cooperation focuses on the optimization of non-cash payment which is secure and transparent. It also focuses on the training for MSME and the shelter development or point of interest on the public service area. According to GO-JEK Chief Public Policy \& Government Relations, the cooperation aims to develop the Denpasar City economy which is already grows rapidly. It is also as a form of modernization of Badung Traditional Market and as a form of noncash payment application through GoPay among the sellers in Badung Market, Denpasar City. It includes vegetables seller, meat seller, and clothes seller. The cooperation aims to make Badung Traditional Market as a smart heritage traditional market. If the seller and buyer in Badung Market are used to transparent and easy non-cash payment, then they may be able to easily accept other digital innovations that can improve the public sector service.

4. Growth Process

Entrepreneur can work because of there is a cohesive team in running a business. Therefore all the plans and operational performance will run productively. Luckily, Bali and Denpasar City have a strong institution in entrepreneurship development process which is Lembaga Perkreditan Desa (LPD). Lembaga Perkreditan Desa (LPD) is a village financial institution that is owned by Desa Adat (customary village), which is made by social bonds and ruled by customary regulations. It helps the community in funding in order to run their business or create a new business.

\section{CONCLUSION}

The development model in this research is based on the model by Joyce, Weil and Calhoun (2011). It is classified into four families, which are information processing family, personal family, social family and behavioral system family. The entrepreneurship model which is done in Badung Market is based on the togetherness concept. This togetherness concept means the concept is of the people, by the people and for the people.

The development process makes the MSME entities in Badung Market, Denpasar more creative and aware in seeing any opportunity to open a new business. This process is certainly influenced by many factors, both internal and external such as, education, sociology, organization, tradition and environment. Those factors formed locus of control, creativity, innovation, implementation, and growth which then will develop to become a great entrepreneur. The development 
process is divided into some development stages which are innovation process, support process, implementation process and growth process.

\section{REFERENCES}

Agustina Tri Siwi, (2019), Kewirausahaan di Era Revolusi Industri 4.0. Jakarta : Mitra Wacana Media.

Alma, Buchari (2017), Kewirausahaan. Bandung : Alfabeta.

Dharmawati Made D., (2017), Kewirausahaan. Jakara : PT. Raja Grafindo.

Darwanto (2012), Peran Entrepreneurship Dalam Mendorong Pertumbuhan Ekonomi dan Peningkatan Kesejahteraan Masyarakat.

Davis, Gordon B. 2013. Kerangka Dasar Sistem Informasi Manajemen. Palembang : Maxikom.

Estia Lidia Paramita, Christantius Dwiatmaja, \& I Wayan Damayana (2015), Penyusunan Model Pengembangan Kewirausahaan Berbasis Kearifan Lokal Dalam Kewirausahaan Desa Adat Di Bali.

Gerilya I Wayan. (2010). Kebudayaan Unggul Inventori Unsur Unggulan Sebagai Basis Kota Denpasar Kreatif. Denpasar: Deva Communication.

Joewono, Handita (2011), Strategi Pengembangan Kewirausahaan Nasional :Sebuah Rekomendasi Operasional, Infokop Volume 19-Juli 2011: 1-23.

Joyce B., Weil M., dan Calhoun E. (2011), Model of Teaching, Edisi Kedelapan. Yogyakarta : Pustaka Pelajar.

Julia (2012), Penerapan Strategi Pembelajaran Active Knowledge Sharing Untuk Meningkatkan Aktivitas dan Hasil Belajar Siswa Kelas XII JPS 2 Perguruan Islam SMA Cerdas Murni TA 201212013, Fakultas Ekonomi Unimed, Medan.

Lestari, Denok. 2015. Developing Communicative Competence of the Students at the Bali Hotel School by Implementing Instructional Role Play. Journal of Business on Hospitality and Tourism. 1(1). http://jbhost.org/ibhost/index.php/ibhost/article/view/31

Malayu, Hasibuan (2016), Manajemen Sumber Daya Manusia, Edisi Revisi, Cetakan Kedua Puluh. Jakarta : PT. Bumi Aksara.

Narottama, Narrarya; Suarja, I Ketut; Lestari, Denok. 2017. Tumpek Wariga as An Ecology Based Local Genius in Supporting Sustainable Tourism: Case Study of Plaga Village, Badung, Bali. International Journal Of Applied Sciences in Tourism And Events, 1(1) p. 43, June 2017. ISSN 2580-5592. Available at:

Http://Ojs.Pnb.Ac.Id/Index.Php/IJASTE/Article/View/523. Cited on: 20 June 2020. Doi: Http://Dx.Doi.Org/10.31940/ljaste.V1i1.523.

Putri Wijayanti \& Alit Suryani (2016), Perbandingan Faktor-Faktor yang Memengaruhi Intensi Berwirausaha Mahasiswa FEB UNUD dan Mahasiswa FEB UNDIKNAS, E-Jumal Manajemen UNUD, Vol. 5 No 3. 
Suhartanto Dwi, Djatnika Tjetjep, Ruhadi dan Triyuni Ni Nyoman, (2017), Ritel Pengelolaan dan Pemasaran. Bandung : Alfabeta.

Srie Sulastri, Atty (2008), Kewirausahaan: Karakteristik Wirausaha. Bandung : Media Grafindo Media Pratama.

Suryana (2013), Kewirausahaan, Pedoman Praktis: Kiat dan Proses Menuju Sukses. Jakarta : Salemba Empat.

Suartha Nyoman, (2016), Revitalisasi Pasar Tradisional Bali Berbasis Pelanggan. Jakarta : PT. Raja Grafindo Persada. 